\title{
O bezpieczeństwie ekonomicznym i dyrektywie Solvency II
}

Alina Klonowska*

\section{Wstęp}

Konsekwencje ekonomiczne pandemii wywołanej przez COVID-19 dotykające przedsiębiorstwa, państwa i globalną gospodarkę sprawiają, że dla wielu milionów podmiotów gospodarczych i nie tylko koniecznością stało się poszukiwanie źródeł wsparcia finansowego w obliczu niepewnie rysującej się przyszłości. W odpowiedzi na poważny wstrząs gospodarczy władze zarówno krajowe, jak i UE podejmują dyskrecjonalne działania, opracowując systemowe rozwiązania antykryzysowe mające wspierać utrzymanie stanowisk pracy. Komisja Europejska przeznaczyła na ten cel 37 mld euro (Gospodarka 2020). Zadanie to jest niezwykle trudne, ale jednocześnie kluczowe dla kondycji ekonomicznej Europy, gdyż samozatrudnieni, małe i średnie przedsiębiorstwa są podstawą europejskiej gospodarki, stanowiąc 99\% wszystkich podmiotów gospodarczych UE. W ostatnich pięciu latach podmioty te stworzyły około 85\% miejsc pracy, zapewniając tym samym dwie trzecie całkowitego zatrudnienia w sektorze prywatnym w całej Wspólnocie.

$\mathrm{Z}$ istoty rzeczy działalność gospodarcza jest obarczona ryzykiem utraty bezpieczeństwa ekonomicznego, którego niechlubną statystykę podbijają periodyczne kryzysy, jednak obecna sytuacja, do której doprowadziły pandemia i konieczne działania władz państwowych, jest nietypowa pod wieloma względami. W kontekście geograficznym zahamowanie aktywności gospodarczej dotyka niemal wszystkie państwa na świecie. W ekonomicznym zaś ujęciu pandemia silnie oddziałuje na stronę zarówno popytową, jak i podażową gospodarek. W przypadku każdego elementu zagregowanego popytu nastąpił bezprecedensowy spadek. Sytuacja wymaga więc niezwykłej determinacji podmiotów gospodarczych oraz spojrzenia decydentów z jak najszerszej perspektywy na możliwości przywracania gospodarek do równowagi ekonomicznej.

* Alina Klonowska - doktor nauk ekonomicznych, Uniwersytet Ekonomiczny w Krakowie, Instytut Finansów, Katedra Zarządzania Ryzykiem i Ubezpieczeń, klonowsa@uek.krakow.pl 
Celem artykułu jest ocenienie bezpieczeństwa ekonomicznego w odniesieniu do pandemii 2020 r. oraz przedstawienie dyrektywy Solvency II jako narzędzia wspierającego władze państw Wspólnoty w dążeniu do zachowania bezpieczeństwa ekonomicznego. W artykule postawiono hipotezę, zgodnie z którą złagodzenie reżimu regulacyjnego ma sprzyjać poprawie sytuacji ekonomicznej państw Unii Europejskiej. Dyrektywa Solvency II, kodyfikując unijne regulacje ubezpieczeniowe, kładzie nacisk na wymogi kapitałowe, odpowiednie zarządzanie ryzykiem oraz sprawozdawczość. W efekcie ma się przyczynić co najmniej do zwiększenia ochrony ubezpieczających i beneficjentów oraz poprawy międzynarodowej pozycji konkurencyjnej ubezpieczycieli i reasekuratorów w UE. Na potrzeby badań dokonano przeglądu literatury przedmiotu oraz przeanalizowano dane pochodzące z raportów Insurance Europe, OECD i Komisji Europejskiej.

W części pierwszej wyjaśniono istotę bezpieczeństwa ekonomicznego i przybliżono jego wybrane uwarunkowania. W części drugiej na podstawie przeglądu literatury przedstawiono znaczenie i rolę ubezpieczeń w gospodarce. W części trzeciej, opartej na analizie bieżącej sytuacji, podjęto próbę udzielenia odpowiedzi na pytanie o to, czy zmiana dyrektywy Solvency II jest koniecznością czy też decyzja o jej wprowadzeniu powinna należeć do władz państwowych.

\section{Zachowanie bezpieczeństwa ekonomicznego w warunkach realnego zagrożenia}

Obserwacja wydarzeń towarzyszących pandemii i jej skutków dowodzi, że oprócz wielu działań podejmowanych w celu ochrony życia i zdrowia ludzkiego zachowanie bezpieczeństwa ekonomicznego jest drugim z kolei najważniejszym celem wymagającym natychmiastowej wytężonej aktywności władz państwowych. Wynika to z tego, że - jak podkreśla N. Roubini (2020) - szok wywołany pandemią, którego doświadczają europejska i światowa gospodarka, jest najpoważniejszy pod względem szybkości i dotkliwości. Ekonomista porównuje obecną sytuację gospodarczą do światowego kryzysu finansowego z 2008 r., a nawet Wielkiego Kryzysu, przypominając, że niekorzystne zmiany parametrów gospodarki w najnowszej historii kryzysów zajęły około trzech lat, a wyniki makroekonomiczne i finansowe będące konsekwencją pandemii zmaterializowały się w ciągu trzech tygodni. Podobnie tę sytuację ocenia Fitch Ratings, który twierdzi, że stanęliśmy w obliczu niepewności powodującej, że ocena przyszłości staje się ogromnym wyzwaniem. Specjaliści spodziewają się spadku globalnego PKB o 2\%, a w przypadku krajów rozwiniętych nawet o 4\% i więcej (Moorcraft 2020). Parlament Europejski szacuje, że potencjalna strata dochodów w skali globalnej może wynieść $0,6 \%$. W przypadku krajów mniej zamożnych wskazuje się na 1,6\% (Delivorias i in. 2020). 
Pochylenie się nad kwestią bezpieczeństwa ekonomicznego jest dziś zatem najwyższą koniecznością, ponieważ termin ten nie odnosi się jedynie do ekonomii - jednym z jego subelementów jest również bezpieczeństwo finansowe. Najczęściej bezpieczeństwo ekonomiczne definiowane jest jako zdolność gospodarki do stabilnego, szybkiego wzrostu i rozwoju gospodarczego (Borkowski 2019). Oznacza również gwarancję płynnego rozwoju gospodarki narodowej (Kostecka-Tomaszewska 2018) i jest kluczowym czynnikiem promującym prywatne inwestycje i wzrost gospodarczy (Poirson 1998). W istocie bezpieczeństwo ekonomiczne to złożona wielopłaszczyznowa kategoria społeczno-ekonomiczna o charakterze zarówno narodowym, jak i międzynarodowym. W statycznym ujęciu związana jest m.in. z rozmiarami, dywersyfikacją i poziomem technologicznym krajowej produkcji przemysłowej oraz ze stopniem samowystarczalności w zakresie żywności i podstawowych surowców oraz paliw (bezpieczeństwo żywnościowe i surowcowe). W ujęciu dynamicznym dotyczy m.in. możliwości i szybkości adaptacji danej gospodarki do zmieniających się warunków (National 1982). Na bezpieczeństwo to składają się całokształt uwarunkowań funkcjonowania gospodarki, brak zagrożeń, a także zdolność gospodarki do rozwoju (Borkowski 2019). Kategoria ta jest więc wypadkową wielu czynników związanych z rolą rynku i państwa: rozwojem gospodarczym i ograniczającymi go barierami, stanem gospodarki i jej struktury, stosunkami i powiązaniami z zagranicznymi partnerami i międzynarodowymi zależnościami (Stachowiak, Stachowiak 2014). To m.in. w tych obszarach tkwią bodźce zarówno destrukcyjne, jak i prorozwojowe, które przekładają się na bezpieczeństwo ekonomiczne kraju.

Jakże aktualne stają się więc dziś formułowane przez wielu ekonomistów koncepcje i postulaty dotyczące tego zagadnienia. Jedną z nich jest koncepcja kolektywnego bezpieczeństwa ekonomicznego, która, jak stwierdził J.S. Nye (1974), w świecie wielu zagrożeń często subtelnych i złożonych zasługuje na większą uwagę. Autor ten twierdzi, że można zidentyfikować co najmniej trzy grupy wartości bliskich prawie wszystkim narodom. Jedną z nich jest minimalny oczekiwany poziom dobrobytu gospodarczego. Pomimo pozornie uniwersalistycznych doktryn „sama natura ekonomii jest zakorzeniona w nacjonalizmie” świadomość współzależności polityki gospodarczej i chęć podjęcia niezbędnych działań instytucjonalnych rozwijają się powoli i nierównomiernie, w miarę jak różne problemy stają się widoczne w dyskusji publicznej. Istotne jest jednak wypracowanie ogólnej zasady poznania oraz troski o zachowanie struktury wspólnych korzyści ekonomicznych, a także zapobieganie poważnemu pozbawieniu dobrobytu gospodarczego zarówno poszczególnych państw, jak i globalnej wspólnoty. H.M. Waite (1935) przypomina o ważnej lekcji z czasów Wielkiego Kryzysu - o bezpieczeństwie ekonomicznym można mówić w kontekście jednostki, rodziny, społeczności, a dopiero potem kraju, co oznacza, że nie można rozwiązać problemów kraju, jeśli nie zostaną rozwiązane problemy jednostki. Przytaczając 
pogląd Z. Stachowiaka i B. Stachowiaka (2014), trzeba uznać, że „budowanie bezpieczeństwa ekonomicznego wymaga podejmowania działań będących odpowiedzią na wyzwania cywilizacyjne oraz odzewem na formułowane i zgłaszane aspiracje społeczeństwa". T.M. Mkrtchyan (2015) dodaje, że zapewnianiu bezpieczeństwa ekonomicznego $\mathrm{w}$ czasie problemów społeczno-ekonomicznych z reguły towarzyszy brak środków zapobiegawczych lub niewdrożenie ich na czas (Mkrtchyan 2015). Przykładem tego mogą być informacje pochodzące $\mathrm{z}$ amerykańskiego raportu przygotowanego przez doradców ekonomicznych prezydenta USA w 2019 r., zgodnie z którymi ryzyko wystąpienia tzw. grypy pandemicznej oceniono na kilka procent i zalecono zastosowanie wczesnych szczepień, aby złagodzić jej skutki (The Council 2019). Dlaczego zatem nie podjęto koniecznych działań prewencyjnych? Można jedynie przypuszczać, że - podobnie jak w przypadku pierwszych symptomów nadchodzącego kryzysu ekonomicznego zaobserwowanych w 2005 r. przez Międzynarodowy Fundusz Walutowy - możliwe było przygotowanie społeczeństwa i gospodarki na wydarzenia, które miały miejsce w ciągu kilku kolejnych lat, jak bowiem napisał niegdyś G.W. Kołodko (2011) nie ma kapitalizmu bez cykliczności procesu reprodukcji makroekonomicznej. Pozostaje tylko kwestia czynników wywołujących recesję. Narażanie dziś systemu ekonomicznego na dotkliwe konsekwencje pandemii może wpłynąć na stabilność finansową na całym świecie (Global Financial 2020). Powrót gospodarek na ścieżkę wzrostu jest zawsze trudny z powodu konieczności podejmowania niełatwych kompromisów w zakresie prowadzonych polityk, a oszacowanie momentu tego powrotu jest niemożliwe. Jak słusznie podkreśla G.W. Kołodko (2011), globalizacja, która przyczyniła się do powstania ogólnoświatowego rynku, nie doprowadziła dotychczas do powstania planetarnego systemu koordynacji polityki gospodarczej, a to może być poważnym utrudnieniem w dążeniu do powrotu gospodarek na ścieżkę wzrostu. Można jednak oczekiwać, że bufory bezpieczeństwa, które powstały w ciągu ostatnich lat długiego wzrostu gospodarek, a także nowe rozwiązania $\mathrm{w}$ różnych obszarach systemu finansowego uchronią gospodarki przed głębokim spadkiem. W tym kontekście pewną rolę odgrywa sektor ubezpieczeń.

\section{Ubezpieczenie a stabilność gospodarcza}

Ubezpieczenie jest nietypowym instrumentem finansowym, który stanowi obietnicę spełnienia określonego świadczenia. Jednak ten myląco subtelny element struktury społeczno-gospodarczej jest nie do przecenienia w kontekście utrzymania stabilności makroekonomicznej, ponieważ w szerokim ujęciu ubezpieczenia pełnią funkcję stabilizatora koniunktury i rynku finansowego. Ubezpieczyciele, mając dostęp do stałego przepływu środków ze składek, 
nawet w okresach skrajnych warunków na rynku finansowym (Finance 2020), wywierają antycykliczny i stabilizujący wpływ na rynki finansowe i gospodarkę. Jak słusznie podkreślają J. Handschke i J. Monkiewicz (2010), ich związek z rynkami kapitałowymi uległ nawet zacieśnieniu. Należy również podkreślić, że oferowana ochrona jest przedmiotem działalności podmiotów tworzących rynek ubezpieczeń, a te zaś są elementem rynkowego systemu finansowego będącego mechanizmem współtworzenia i przepływu środków pieniężnych, który warunkuje sprawne funkcjonowanie całej gospodarki i sprzyja inkluzywnemu wzrostowi gospodarczemu (Finance 2020).

Na początku lat dwutysięcznych w literaturze przedmiotu dominował pogląd, że ciężar poznawczy dotyczący sektora bankowego oraz giełdy należy przenieść i ukierunkować na analizę sektora finansowego i polityki makroekonomicznej ze szczególnym uwzględnieniem ubezpieczeń. $Z$ czasem więc liczba pozycji literaturowych poświęconych badaniom dotyczącym roli i znaczenia ubezpieczeń we współczesnej gospodarce wzrosła. Wnioski płynące $\mathrm{z}$ badań nie pozostawiają wątpliwości co do istotnej roli ubezpieczeń w gospodarce:

- Zarówno ubezpieczenia majątkowe, jak i ubezpieczenia na życie przyczyniają się do wzrostu gospodarczego w krajach rozwijających się (Outrevillle 1990).

- Działalność ubezpieczycieli, niezależnie od rodzaju oferowanej ochrony, może przyczynić się do wzrostu gospodarczego (Skipper 1997).

- Rozwój sektora ubezpieczeń i pośrednictwa finansowego zwiększa całkowitą produktywność czynników produkcji, a tym samym sprzyja efektywnej alokacji kapitału (Levine i in. 2000).

- Ubezpieczenia nie tylko ułatwiają transakcje gospodarcze, przenoszą ryzyko i przyznają świadczenia ubezpieczeniowe, lecz również promują pośrednictwo finansowe (Ward i Zurbruegg 2000).

- Istnieje silna długoterminowa zależność ekonomiczna między działaniami rynku ubezpieczeniowego a wzrostem gospodarczym (Pradhan i in. 2017).

- Ubezpieczenia na życie wpływają na wzrost gospodarczy jedynie w krajach rozwiniętych, podczas gdy ubezpieczenia inne niż ubezpieczenia na życie wpływają na wzrost w krajach zarówno rozwiniętych, jak i rozwijających się (Arena 2008).

- Wpływ inwestycji ubezpieczeniowych i składek na PKB w zakresie ubezpieczenia na życie w państwach UE jest pozytywny. W przypadku nowych członków UE wysokie znaczenie ma ubezpieczenie od odpowiedzialności cywilnej (Haiss i Sümegi 2008).

- Rozwój rynku ubezpieczeń na życie ma istotny wpływ na wzrost gospodarczy (Chen i in. 2012). 
- Ubezpieczenia stały się obecnie głównym składnikiem gospodarek krajów rozwiniętych. Udział ubezpieczeń w PKB poszczególnych państw jest coraz wyższy i oscyluje wokół $12 \%$ w niektórych krajach (Cristea i in. 2014).

Bez wątpienia sektor ubezpieczeń, stanowiący kluczowy elementem każdego systemu społeczno-gospodarczego, ma duże znaczenie także w skali globalnej. W 2017 r. przemysł ubezpieczeniowy wzrósł o ponad 4\%, a łączna składka wyniosła 4,7 bln EUR (Global Insurance 2019). W odpowiedzi na bezprecedensowy wzrost składki ubezpieczeniowej w 2018 r. J.J. Haegeli (2019) ze Swiss Re powiedział, że „rola sektora ubezpieczeń w długoterminowym inwestowaniu staje się ważniejsza niż kiedykolwiek". Państwa Unii Europejskiej tworzą jeden z najważniejszych rynków ubezpieczeniowych na świecie. Europejski przemysł ubezpieczeniowy wypłaca prawie 1100 mld EUR rocznie w formie odszkodowań i świadczeń, zatrudnia ponad 900000 osób, a ulokowane na rynkach finansowych środki sięgają 10200 mld EUR (Ambitions 2020). To sprawia, że branża ubezpieczeniowa jest nie tylko największym inwestorem instytucjonalnym w Europie, lecz również ważnym dostawcą stabilnego i długoterminowego finansowania różnych dziedzin, także tych innowacyjnych.

Mimo że europejski przemysł ubezpieczeniowy ma obecnie duże znaczenie, to istnieją poważne zagrożenia dla dynamiki jego rozwoju, znaczenia w gospodarce, a w konsekwencji - pozycji w skali globalnej. Masowa emerytura, której wkrótce potrzebować będą beneficjenci zaliczani do wyżu demograficznego, jest poważnym wyzwaniem dla finansów przedsiębiorstw ubezpieczeniowych. Ocenia się, że w ciągu najbliższych 20 lat ludność Europy w wieku 65+ może stanowić $28 \%$. Będzie to najwyższy poziom w porównaniu z Chinami $(23,8 \%)$ lub USA (21,6\%) (The Drive 2020). Ponadto - w odróżnieniu od europejskiego rynku ubezpieczeń, który traci kolejne motywatory rozwoju - dynamiczna ewolucja azjatyckiego rynku ubezpieczeń opiera się głównie na rosnącym udziale klasy średniej tego społeczeństwa. W Afryce niezwykle korzystny dla sektora ubezpieczeń jest wzrost populacji w ogóle. Obydwa motywatory tracą na znaczeniu w europejskich warunkach. Dlatego też, jeśli chodzi o inne czynniki determinujące przyszłe znaczenie i rolę europejskiego sektora ubezpieczeń, niezwykle istotne staje się wprowadzanie rozwiązań pozytywnie wpływających na rozwój tego sektora i umacniających jego pozycję nie tylko w konkretnej gospodarce, lecz również globalnie. Aby zatem umożliwić przedsiębiorstwom ubezpieczeniowym maksymalizowanie ich potencjału inwestycyjnego, a tym samym przyczynić się do wzrostu gospodarczego, należy wprowadzić odpowiednie warunki regulacyjne. Biorąc pod uwagę cykliczne kryzysy gospodarcze, które mogą skłonić przedsiębiorstwa ubezpieczeniowe do podejmowania coraz bardziej ryzykownych lokacji, wydaje się, że konieczna jest dyskusja na 
szczeblu europejskim poparta badaniami, które wskażą, jak daleko można posunąć się w polityce lokacyjnej w określonych warunkach, tym bardziej że odsetek zysków przemysłu ubezpieczeniowego z dochodów z inwestycji w okresie 2014-2018 wyniósł 90\%.

\section{Korekta dyrektywy Solvency II - konieczność czy wybór?}

Do głównych zamierzeń Komisji Europejskiej (KE), które mają być realizowane w latach 2019-2024, należy stworzenie dobrze prosperującej, zrównoważonej i konkurencyjnej Europy. Celem, który zwraca szczególną uwagę, jest utrzymanie globalnie konkurencyjnego unijnego przemysłu (re) ubezpieczeń. Realizacja tych zamierzeń powinna uwzględniać rolę branży ubezpieczeniowej, która może i powinna być kluczowym czynnikiem w dążeniu do zrównoważonej europejskiej gospodarki. Jednak, jak twierdzi A. Brandstetter, osiągniecie tych celów wymaga zmiany dyrektywy II (Solvency 2020).

W typowych warunkach gospodarczych postawione cele zapewne byłyby stopniowo realizowane zarówno w odniesieniu do gospodarki, jak i koniecznej korekty prawa. Jednak pandemia, postrzegana jako największe globalne ryzyko katastroficzne, które może doprowadzić do upadku gospodarczego (Jonas 2013), przyspieszyła korektę obowiązujących regulacji i zmusiła branżę ubezpieczeniową do szybszych zmian ze względu na zmianę potrzeb konsumentów, którzy obecnie skupiają się głównie na ubezpieczeniach na życie (US insurance 2020). Podkreśla się, że w przyszłości sektor ubezpieczeń zostanie poddany ciężkiej próbie związanej ze wzrostem trudności na rynku i utrzymaniem działalności. Agencja Fitch ocenia, że pandemia spowalnia rozwój rynku ubezpieczeń i wywiera presję na jego rentowność (Coronavirus 2020).

Europejski Urząd Nadzoru Ubezpieczeń i Pracowniczych Programów Emerytalnych (EIOPA) we współpracy z innymi europejskimi urzędami nadzoru oraz Europejską Radą ds. Ryzyka Systemowego (ERRS) przygotował zestawienie rekomendacji dla sektora ubezpieczeniowego. Obecnie jego najważniejszym zadaniem jest zapewnienie ciągłości działań w zakresie utrzymania świadczenia usług, w tym wypłacalności przedsiębiorstw ubezpieczeniowych (Ambitions 2020).

Jednocześnie z początkiem 2020 r. rozpoczęto prace nad rewizją najważniejszej dyrektywy regulującej działalność ubezpieczeniową. Ostatnie lata obowiązywania Solvency II dowodzą, że regulacje pozwoliły na osiąganie ogólnych celów i pod wieloma względami oddziaływały korzystnie na przemysł ubezpieczeniowy, niemniej jednak wymagają one ukierunkowanych zmian. Ocenia się, że zmiana dyrektywy, mająca na celu zwiększenie dostępności odpowiednich długoterminowych i zrównoważonych zasobów, może przyczynić się do utrzymania, a nawet zwiększenia wkładu sektora ubezpieczeń we wzrost 
gospodarczy Europy poprzez. KE zwróciła się zatem do europejskiego organu nadzoru ubezpieczeń (EIOPA) z prośbą o udzielenie porady technicznej. Przegląd dyrektywy Solvency II stał się okazją do przedyskutowania ograniczeń wynikających z pewnej ostrożności (uznawanej za nieuzasadnioną). Na konferencji KE dotyczącej przeglądu Solvency II dyrektywę tę określono mianem jednego z najbardziej konserwatywnych reżimów ostrożnościowych na świecie, który wymaga korekty, zwłaszcza jeśli chodzi o zmniejszenie barier w przypadku inwestycji długoterminowych. Wynika to z faktu, że ryzyko związane $\mathrm{z}$ inwestycjami i gwarancjami długoterminowymi jest niższe, niż obecnie zakłada Solvency II (Solvency 2020). Ponadto wyniki badań przeprowadzonych przez Insurance Europe dowodzą, że prawie 50\% z 87 przedsiębiorstw ubezpieczeniowych z 17 rynków europejskich uznało reżim regulacyjny dyrektywy za utrudnienie $\mathrm{w}$ inwestowaniu $\mathrm{w}$ aktywa związane $\mathrm{z}$ realną gospodarką. Ta cecha wysuwa się na pierwszy plan szczególnie w kontekście utrzymania przez sektor ubezpieczeń funkcji, jaką obecnie pełni w gospodarce.

W efekcie zaproponowano zmianę ponad 100 punktów, uwzględniając zagadnienia dotyczące tworzenia „wypłacalnościowych” rezerw techniczno-ubezpieczeniowych, sprawozdawczości i stosowania zasady proporcjonalności, a także kwestię wymogów kapitałowych i ujmowania oczekiwanych zysków z przyszłych składek. Wpisuje się w to również aktywność inwestycyjna przedsiębiorstw ubezpieczeniowych, która co do zasady przyczynia się do ostrożnego inwestowania, a co za tym idzie - stabilizowania rynków finansowych. Podkreśla się jednak, że zmiany te mogą być tak rewolucyjne, że nie przyczynią się do zwiększenia stabilności i bezpieczeństwa rynku ubezpieczeniowego, a koszty skokowego wzrostu bezpieczeństwa systemu mogą obciążyć klientów (Finance 2020).

Określone pierwotnie priorytety KE zostały poddane bezwzględnej rewizji (Ambitions 2020), w wyniku której nowym celem władz europejskich stała się zmiana kierunku polityki na wspierającą przedsiębiorców. I chociaż dobra kondycja sektora ubezpieczeń obserwowana podczas załamania gospodarczego poprzedzającego obecny kryzys ekonomiczny dowodzi, że konserwatywna polityka inwestycyjna i właściwe zarządzanie ryzykiem są najlepszą strategią zabezpieczania się przed skutkami zapaści, to jednak kondycja ta może się zmienić. Przeprowadzone testy warunków skrajnych wykazały, że sektor jest dobrze skapitalizowany i odporny na poważne wstrząsy systemowe. W razie wystąpienia potrzeby ograniczenia ryzyka i skutków pandemii w przypadku tego sektora EIOPA nie wykluczyła wdrożenia odpowiednich narzędzi określonych w systemie Wypłacalność II w celu utrzymania ochrony ubezpieczonych oraz zachowania stabilności finansowej (EIOPA 2020). 


\section{Zakończenie}

Analiza przeprowadzona na podstawie przeglądu literatury przedmiotu i raportów powszechnie szanowanych instytucji, a także obserwacji bieżącej sytuacji pandemicznej dowodzi, że istnieją przesłanki uzasadniające konieczność zmiany dyrektywy Solvency II. Konsekwencje pandemii wstrząsnęły gospodarką europejską i wymusiły dostosowanie prawa zarówno do zmieniającego się otoczenia, jak i nowych warunków gospodarowania. Mimo że w gospodarce rynkowej rola państwa w kształtowaniu bezpieczeństwa ekonomicznego jest ograniczona, to jednak zawsze pozostaje ona newralgiczna dla zapewnienia sprawności funkcjonowania krajowego systemu gospodarczego, w szczególności w okresie koniecznego przeciwstawiania się negatywnym oddziaływaniom zewnętrznym. W tym wypadku wymagane jest podjęcie działań, które utrzymają ważną pozycję branży ubezpieczeniowej i na nowo odkryją potencjał ubezpieczeń w gospodarce, a tym samym umożliwią wspieranie władz w dążeniu do zachowania bezpieczeństwa ekonomicznego Europy. I chociaż wprowadzenie zmian staje się koniecznością, to jednak decyzja o złagodzeniu zapisów dyrektywy Solvency II nadal należy do władz europejskich.

\section{Bibliografia}

Ambitions for Europe - Overview (2020), https://insuranceeurope.eu/ambitions-europe-overview (data dostępu: 15.05.2020).

Arena M. (2008), Does insurance market activity promote economic growth? A cross-country study for industrialized and developing countries, „Journal of Risk and Insurance", 75(4).

A risk-based regime for Europe (2020), https://www.insuranceeurope.eu/solvency-ii (data dostępu: 3.06.2020).

Borkowski M. (2019), Bezpieczeństwo ekonomiczne Szwecji na tle państw OECD, „Studia Ekonomiczne, Zeszyty Naukowe Uniwersytetu Ekonomicznego w Katowicach", 379.

Chen P.F., Lee Ch.Ch., Lee Ch.F. (2012), Insurance market activity and economic growth: An international cross-country analysis, „Journal of International Development", 7(24).

Coronavirus Pandemic to Slow Austria 's Insurance Market Growth (2020), https:// www.fitchratings.com/research/insurance/coronavirus-pandemic-to-slow-austria-insurance-market-growth-27-05-2020 (data dostępu: 8.06.2020).

Cristea M., Marcua N., Cârstina S. (2014), The Relationship between Insurance and Economic Growth in Romania Compared to the Main Results in Europe - A Theoretical and Empirical Analysis, „Procedia Economics and Finance”, 8. 
Delivorias A., Scholz N. (2020), Economic impact of epidemics and pandemics, https://www.europarl.europa.eu/RegData/etudes/BRIE/2020/646195/EPRS BRI (2020)646195_EN.pdf, PE 646.195 (data dostępu: 15.04.2020).

EIOPA (2020), EIOPA: wskazówki dla sektora ubezpieczeniowego w zwiąku z pandemia COVID-19, Europejski Urząd Nadzoru Ubezpieczeń i Pracowniczych Programów Emerytalnych, http://www.beinsured.pl/artykuly/eiopa-wskazowki-dla-sektora-ubezpieczeniowego-w-zwiazku-z-pandemia-covid-19,6695.html (data dostępu: 1.06.2020).

Finance Sustainable EU Economic Growth (2020), https://insuranceeurope.eu/ sites/default/files/attachments/Ambitions\%20for\%20Europe\%20-\%20Finance $\% 20$ sustainable $\% 20 \mathrm{EU} \% 20$ economic\%20growth.pdf (data dostępu: 3.06.2020).

Global Financial Stability Report (2020), International Monetary Fund, https:// www.imf.org/en/Publications/GFSR/Issues/2020/04/14/global-financial-stability-report-april-2020 (data dostępu: 15.04.2020).

Global Insurance Trends and Forecasts, https://www.mckinsey.com/industries/ financial-services/our-insights/2019-global-insurance-trends-and-forecasts (data dostępu: 17.05.2020).

Gospodarka i miejsca pracy podczas pandemii koronawirusa, https://ec.europa. eu/info/live-work-travel-eu/health/coronavirus-response/jobs-and-economy-during-coronavirus-pandemic_pl (data dostępu: 3.06.2020).

Haegeli J.J. (2019), Global insurance premiums exceed USD 5 trillion for the first time as pivot east continues, Swiss Re Institute's latest sigma says, https:// www.swissre.com/media/news-releases/nr-20190704-sigma-3-2019.html (data dostępu: 13.05.2020).

Haiss P., Sümeg K. (2008), The relationship between insurance and economic growth in Europe: a theoretical and empirical analysis, „Empirica”, 35.

Handschke J., Monkiewicz J. (red.) (2010), Ubezpieczenia. Podręcznik akademic$k i$, Poltex, Warszawa.

Jonas O. (2013), Pandemic Risk, The World Bank, https://www.worldbank.org/ content/dam/Worldbank/document/HDN/Health/WDR14_bp_Pandemic_ Risk_Jonas.pdf $+\& c d=1 \& h l=p l \& c t=c \ln k \& g l=p l \& c l i e n t=$ firefox $-b-d \quad($ data dostępu: 2.06.2020).

Kołodko G.W. (2011), Świat między kryzysami - wstęp do wydania polskiego [w:] N. Roubini, S. Mihm, Ekonomia kryzysu, Wydawnictwo Wolters Kluwer, Warszawa.

Kostecka-Tomaszewska L. (2018), Economic security of China: The implications of the belt and road initiative, „Optimum Economic Studies”, 4(94).

Levine R., Loayza N., Beck T. (2000), Financial intermediation and growth: causality analysis and causes, „Journal of Monetary Economics”, 46(1). 
Mkrtchyan T.M. (2015), State Economic Security System and Its Components, 4th Int'l Conference on Research in Humanities, Sociology \& Corporate Social Responsibility (RHSCSR'15) Sept. 25-26, 2015 Penang (Malaysia), https://icehm.org/upload/3757ED915013.pdf (data dostępu: 15.05.2020).

Moorcraft B. (2020), Fitch Ratings: COVID-19's negative impact on the global insurance industry, https://www.insurancebusinessmag.com/asia/news/breaking-news/fitch-ratings-covid19s-negative-impact-on-the-global-insurance-industry-220124.aspx (data dostępu: 25.05.2020).

Nye J.S. (1974), Collective Economic Security, „International Affairs”, 50(4), Oxford University Press on behalf of the Royal Institute of International Affairs Stable, https://www.jstor.org/stable/2615925 (data dostępu: 1.04.2020).

Outreville J.F. (1990), The Economic Significance of Insurance Markets in Developing Countries, „The Journal of Risk and Insurance”, 57(3).

Poirson H. (1998), Economic Security, Private Investment, and Growth in Developing Countries, Working Paper, International Monetary Fund, WP/98/4.

Pradhan R.P. i in. (2017), Insurance - growth nexus and macroeconomic determinants: evidence from middle-income countries, „Empirical Economics”, 52(4).

Roubini N. (2020), Coronavirus pandemic has delivered the fastest, deepest economic shock in history, https://www.theguardian.com/business/2020/mar/25/ coronavirus-pandemic-has-delivered-the-fastest-deepest-economic-shock-in-history (data dostępu: 31.03.2020).

Skipper H.D. (1997), Foreign Insurers in Emerging Markets: Issues and Concerns, Occasional Paper 97-2, Center for Risk Management and Insurance.

Solvency II 2020 review: why would one of the world's most prudent and conservative prudential regimes need "prudential enhancements"? (2020), https:/ww.insuranceeurope.eu/solvency-ii-2020-review-why-would-one-world-s-most-prudent-and-conservative-prudential-regimes-need (data dostępu: 8.06.2020).

Stachowiak Z., Stachowiak B. (2014), Kontrowersje i dylematy rozwiazania problemu bezpieczeństwa ekonomicznego w Polsce, „Ekonomia bezpieczeństwa i logistyka, Zeszyty Naukowe AON", 3(96).

The Council of Economic Advisers (2019), Mitigating the Impact of Pandemic Influenza through Vaccine Innovation, https://www.whitehouse.gov/wp-content/uploads/2019/09/Mitigating-the-Impact-of-Pandemic-Influenza-through-Vaccine-Innovation.pdf (data dostępu: 15.04.2020).

The drive for transformation and growth, 2020 Global Insurance Outlook (2020), https://www.ey.com/Publication/vwLUAssets/Insurance_outlook/\$FILE/eyglobal-insurance-outlook.pdf (data dostępu: 23.04.2020).

US insurance market trends during the pandemic, https://www.mckinsey.com/ industries/financial-services/our-insights/us-insurance-market-trends-during-the-pandemic (data dostępu: 8.06.2020). 
Waite H.M. (1935), Economic Security, „Journal (American Water Works Association), Wiley", 27(8), https://www.jstor.org/stable/41226407 (data dostępu: 1.04.2020).

Ward D., Zurburegg R. (2003), Does Insurance Promote Economic Growth? Evidence form OECD Countries, „Journal of Risk and Insurance”, 67(4).

\section{Streszczenie}

Celem artykułu jest ocena bezpieczeństwa ekonomicznego państw Unii Europejskiej w odniesieniu do pandemii COVID-19 i przedstawienie dyrektywy Solvency II w roli narzędzia wspierającego władze państw Wspólnoty w dążeniu do zachowania bezpieczeństwa ekonomicznego.

Hipoteza: złagodzenie reżimu regulacyjnego dyrektywy Solvency II sprzyja poprawie sytuacji ekonomicznej państw Unii Europejskiej.

Metoda: badania przeprowadzono na podstawie przeglądu literatury przedmiotu, a także analizy danych pochodzących z raportów Insurance Europe, OECD oraz Komisji Europejskiej.

Rezultaty: z przeprowadzonych badań wynika, że istnieją merytoryczne przesłanki uzasadniające konieczność wprowadzenia zmian w dyrektywie Solvency II na rzecz wspierania sytuacji ekonomicznej państw. Pandemia COVID-19 przyczyniła się do drastycznej zmiany warunków ekonomicznych, a złagodzenie zapisów dyrektywy może korzystnie wpłynąć na sytuację ekonomiczną państw Wspólnoty, jednak decyzja o zmianie dyrektywy należy do władz europejskich.

Słowa kluczowe: bezpieczeństwo ekonomiczne, sektor ubezpieczeń, prawo JEL: G22, O40.

\section{Summary}

\section{On economic security and the Solvency II Directive}

The purpose of the article is an attempt to evaluate the economic security of European Union countries from the perspective of the ongoing COVID-19 pandemic and to present the Solvency II Directive as an instrument to support the authorities of the Community countries in their pursuit of preserving economic security.

Hypothesis: alleviating the regulatory regime of the Solvency II Directive contributes to improving the economic situation of European Union countries. 
Method: for the purposes of the study, the literature on the subject was reviewed, and data analysis was performed on the reports of Insurance Europe, OECD, and the European Commission.

Conclusion: The research indicates that there are substantive premises that justify the necessity to amend the Solvency II Directive to support the economic situation of the countries. In the face of the shocking changes in economic conditions caused by the COVID-19 pandemic, alleviating the Directive's provisions will ultimately have a positive effect on the economic situation of the Community countries. However, this decision remains in the sphere of possible choice of European authorities.

Keywords: economic security, insurance industry, law 